\title{
Colloquial Speech of University Students' Utterance
}

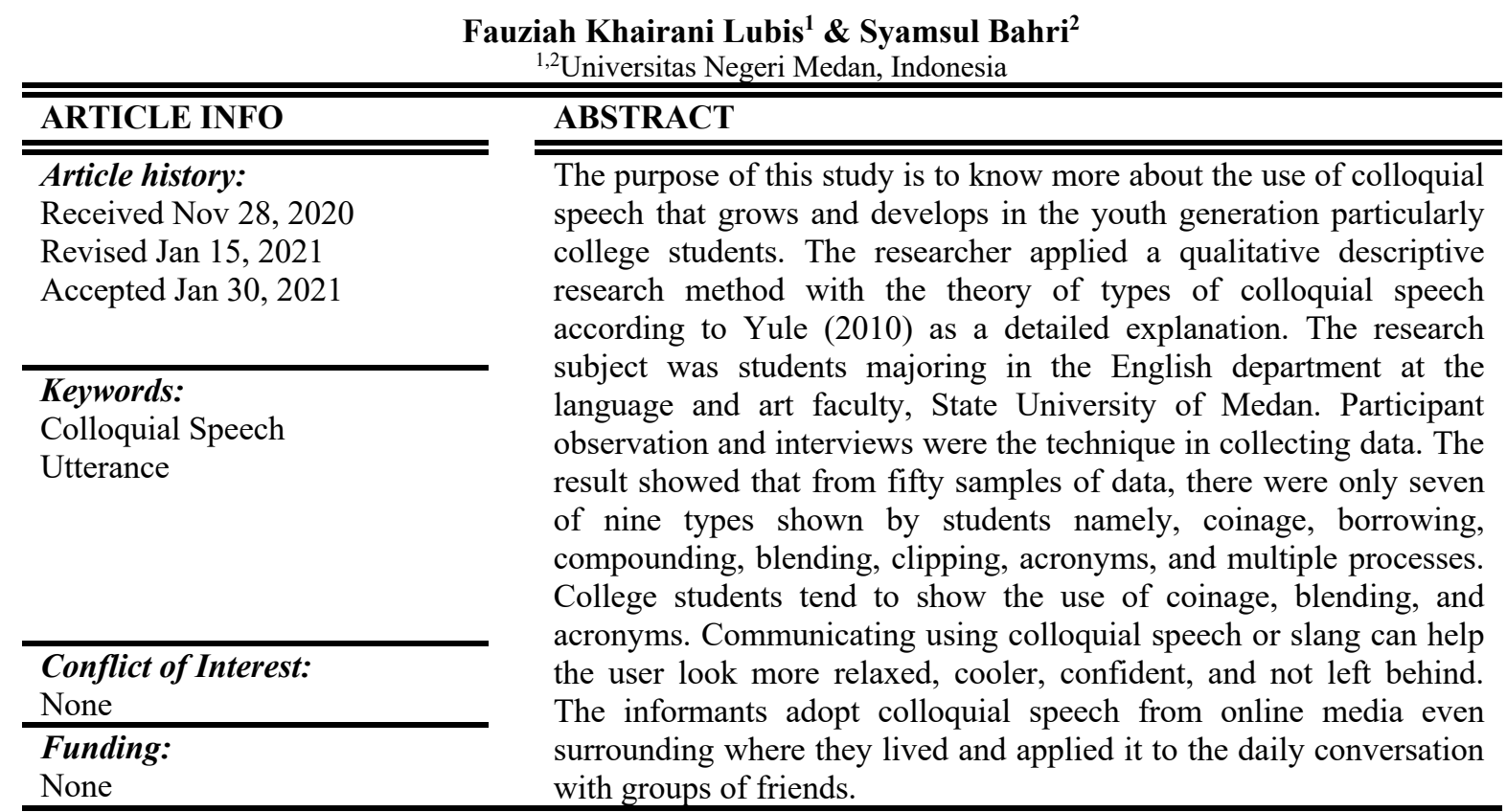

Corresponding Author: Syamsul Bahri, S.S., M.Hum. Lecturer at English and Literature Department, Faculty Languages and Arts, Universitas Negeri Medan. E-mail: syamsul.bahri0401@gmail.com

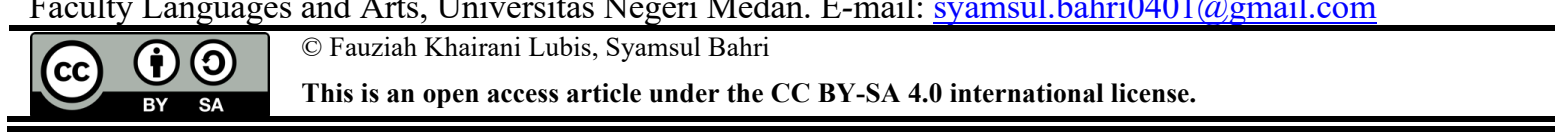

\section{Introduction}

Sociolinguistics is a branch of language which studies or discusses the social aspects of language. Holmes in Chaer (2003) stated that "Sociolinguistics is the study of the relationship between language and society." The main issue discusses or studies in sociolinguistics, those are reviewing the language in the context of social and cultural, connecting factors linguistic, characteristics of language, language diversity, situation, social factors, and cultural as well as reviewing the social functions and the use of language in society. Besides, sociolinguistics studies how language varieties differ between groups separated by certain social variables.

Language can be varieties based on several different points of view including the way it is used, language varieties are classified in the formality, stratification and the various professional fields to which the lexicon of the language is normally associated, such as the language varies according to formality there is formal and informal language. The formal language variety is referred to the variety used in writing official letters, government documents, research reports, business meetings, college lectures, and academic seminars. Meanwhile, the informal English language variety is sometimes referred to as the casual or colloquial style. Casual or colloquial words are more in spoken than in the written English variety. We use informal words when talking with family, friends at mealtime, neighbors, at school, at works, or among colleagues. Informal language is also known as slang words or colloquial speech.

According to Yule, Slang, or Colloquial Speech describes words or phrases that are used instead of more everyday terms among younger speakers and other groups with special interests. Colloquial speech is a type of word that is also made through a different process of word-formation. Some of them have a very short span of existence whereas some are as old as the language itself. According to Yule (2010) Word formation of colloquial speech divided into several types, they are: a) Coinage, b) Borrowing, c) Compounding, d) Blending, e) Clipping, f) Back-formation, g) Derivation, h) Acronyms and i) Multiple Process.

Colloquial speech or slang has several functions. According to Yachun and Yanhong (2013), there are three functions of slang, they are: a) Pursuit of self-identity, b) emotive feeling of the Slang Users, c) achieving 
politeness. Also, according to Gerber (1968) that teens use slang words in sentences shorter, faster, and easier to say. Slang words also can express anger and accept unsettling experiences by translating the formal words into slang and getting a laugh (Guitar, 1963).

Nowadays, Colloquial Speech many used by University Students'. University Students utter it when they talked with their friend. Colloquial speech that University students utter usually created by their creativity. University students' utterances have several special characteristics, namely brief and creative. The utterance was developed from small groups to spread and spread throughout the country. The words used in the utterance tend to be short if there are long words that will be shortened through a morphological process. University students' utterances will continue to develop following the times. According to Namvar (2014), colloquial speech is frequently used by the youth generation caused of the young generation using the internet a lot nowadays, and media has the most important role. Previous studies conducted to improve, develop, foster, and preserve slang or colloquial speech such as (1) Slang and Colloquialism in Cameroon English Verbal Discourses by Epoge, N. K., 2012. (2) The Reception of Subtitled Colloquial Language in Catalan: An Eye-Tracking Exploratory Study by Fernandez, A., Matamala, A., \& Vilaro, A., 2014. (3) Linguistic and Social Features of Slang by Izmaylova, G. A., Zamaletdinova, G. R., \& Zholshayeva, M. S., 2017 (4) A Study of English Translation of Colloquial Expression in Two Translations of Jamalzadeh: Once Upon a Time and Isfahan is Half the World by Jalalpour, E., \& Tabrizi, H. H., 2017. (5) Code-Switching, Swearing, and Slang: The Colloquial Register of Basque in Greater Bilbao by Lantto, H., 2012. (6) Features of Youth Slang Functioning by Zamaletdinova, G. R., \& Izmaylove, G. A., 2016.

Research on colloquial speech had often been done. The difference from some previous studies is the object of research. The object of research in this study was students majoring in the English department at the language and art faculty, Universitas Negeri Medan. Researchers are interested in doing this research due to several reasons: a) researchers found many colloquial speeches used by students when talking to their friends. b) colloquial speech used by each student is different according to their background, culture, and habits so that researchers are interested in researching it. c) colloquial speech develops over time by the times, which makes researchers feel it is important to examine the colloquial speech that often arises among students.

\section{Literature Review}

Sociolinguistics is a branch of language which studies or discusses the social aspects of language. Sociolinguistics derived from the word "socio" and "linguistic" (Nababan,1993). Socio similar to the word of social that relates to the word of society. Linguistics is a study that discusses the language, especially in particular elements and those elements among them. Thus, sociolinguistics is the study that constructs theories about social relations with the language.

A study of sociolinguistics is the study of the language that is associated with social conditions. Similar to the foregoing view, Richard (2001: 13) in Chaer revealed that Sociolinguistics is the study that discusses language to consider the relationship between a language and the society especially the speakers of the language itself. Holmes in Chaer (2003) stated that "Sociolinguistics is the study of the relationship between language and society." This science learns why we talk differently in a different social context. Sociolinguistics is a study that identifies the language of the social function of a language and how language is used to bring a certain social meaning.

Sociolinguistics means the study of language that is associated with the condition of a particular society. The main issue discusses or studies in sociolinguistics, those are reviewing the language in the context of social and cultural, connecting factors linguistic, characteristics of language, language diversity, situation, social factors, and cultural, as well as reviewing the social functions and the use of language in society. In the English language means sociolinguistics is a subdiscipline of linguistics that studies language in its usage in social relations. Sociolinguistics concentrates on how language assortments vary between bunches isolated by certain social factors. Language can be varieties based on several different points of view including the way it is used, language varieties are classified in the formality, stratification and the various professional fields to which the lexicon of the language is normally associated, such as the language varies according to formality there is formal and informal language.

The formal language variety is referred to as the variety used in writing official letters, government documents, research reports, business meetings, college lectures, and academic seminars. Formal language is used in a formal situation. As we see the meaning of formal language variety above, a language almost used in formal situations and formal places such as in the college, office, etc. But not all people used formal 
language in their everyday conversation. They used informal language when they do communication although they used it in a formal place.

The casual English language assortment is once in a while alluded to as the easygoing or informal style. Casual or colloquial words are more in spoken than in the written English variety. We use informal words when talking with family, friends at mealtime, neighbors, at school, at works, or among colleagues. Informal language is also known as slang words or colloquial speech.

According to Yule, Slang, or Colloquial Speech describes words or phrases that are used instead of more everyday terms among younger speakers and other groups with special interests. Slang language comes from Norway "Slengeord" which means the language of insult or as unofficial language varieties, and not raw seasonal nature. Used by a particular social group for internal communication, which is intended for nonmembers that don't understand. The meaning of colloquial speech itself is the use of informal words and expressions that are not considered standard in the speaker's dialect or language. Colloquial speech is a nonstandard word which popular and used by certain groups, such as youth groups, college groups, jazz groups, and so on.

Holmes (2001) stated that people in a society may speak some varieties of language by different social climates they meet. Indeed, people should know whether they are in an informal or formal situation. When people speak, they should understand well about the situation around them. It is significant in picking a proper language that will be utilized, formal style, or non-formal one. The use of colloquial speech can be affected by some social factors such as age, gender, status, etc. Colloquial speech is another area of vocabulary which reflects a person's age.

In conclusion, colloquial speech is an informal word that having by a certain group or community. The meaning of colloquial speech just can be understood by that group and the other group may be difficult to know the meaning of it. Colloquial speech is more used by almost all people when they speak to others. Colloquial speech easier helps people to convey their information to other people. Colloquial speech is often used by teenagers and youth because they are cheerful, creative, and full of new ideas.

According to Yule (2010) Word formation of colloquial speech divided into several types, they are: a) Coinage, b) Borrowing, c) Compounding, d) Blending, e) Clipping, f) Back-formation, g) Derivation, h) Acronyms and i) Multiple Process.

a) Coinage is the invention of totally new terms and they tend to become everyday words in the language (Yule, 2010). The slang words categorized as coinage here are mostly used to express a joke to other students, such as the word 'cemen' which refers to a coward, 'comel' which is the term for someone who cannot keep a secret and 'culun' which refers to (like) a fool.

b) Yule (2010) has stated that borrowing is taking over words from other languages. For this procedure, the model is Me Gusta and Le. The word Le is gotten from the French language which signifies "the" in English. Me Gusta is a colloquial phrase from Spain which means 'I like It'. Me Gusta represents joy and excitement in an awkward moment. The words borrowed from Betawi are gue to mean as pronoun I and lo as pronoun you. There are two Javanese words as the word 'katrok' for hick or countrified and 'koplak' for crazy or 'idiot'. Last, the rest of the words has been borrowed from Sundanese vocabularies, such as the term 'garing', which means unfunny joke, 'jangar' for headache, and 'jomblo' which refers to a single.

c) Compounding is the process of joining two separate words to produce a single form (Yule, 2010). The term 'ilfeel' or to lose feeling by someone is mostly spoken to show displeasure about something. This term is used by combining the word ill and feel. The term speechless is usually used by the students when they get nervous or when they have no words to say. This term is used by combining the word spoken and less.

d) 'Ansos' and 'Jones' could be categorized into blending, which is a combination of two separate forms to produce a single new term (Yule, 2010). Commonly, mixing takes the start of a single word and going along with it to the furthest limit of another word. The word 'ansos' originates from 'hostile to social' or in English 'not friendly'; an (against) or not got together with 'sos' (social). 'Jones' comes from 'jomblo ngenes' or in English forever alone; jo (jomblo) or single and nes (ngenes) or pathetic. This word becomes the slang word because most 'wancaker' (users and visitors of 1cak.com) uses this word to reveal their condition of being single in a certain group. It clearly shows that they use slang language to express their idea or to feel like a member of the group.

e) Clipping is a process that creates a new word by makes it shorter than the word before by deleting one or more syllables (Yule, 2010). Typically, this word-formation process uses only one syllable. 
For example, the word 'Genius' clarifies another word. 'Star' is a slang language that originates from the word 'proficient'. The basic word for the slang 'pro' comes from the word professional in Bahasa. It contains four syllables (pro $+\mathrm{fe}+\mathrm{sio}+\mathrm{nal}$ ) which are organized as $\mathrm{CCV}+\mathrm{CV}+\mathrm{CVV}+\mathrm{CVC}$. The section procedure in this word arrangement is finished by keeping the main syllable 'professional' and precluding the remainder of the syllables. This slang appears in the clipping process to make an easier pronunciation of professional as 'pro'. It is used by 'wancaker' as their language to make a word short for it to say or even to write, and it has become a popular language. This slang language has the purpose of giving a representative of the entire word by the first syllable. Another example of clipping words is 'beb' from the word 'baby', bro from the word 'brother', sis from the word 'sister', fav from the word 'favorite', and geez from the word 'Jesus'.

f) According to Yule (2010), a very specialized type of reduction process is known as backformation. Commonly, expression of one sort (typically a thing) is diminished to frame an expression of another kind (normally an action word). A genuine case of backformation is the procedure whereby the thing TV previously came into utilization and afterward the action word broadcast was made from it. Different instances of words made by this procedure are: give (from "gift"), act out (from"emotion"), enthuse (from "excitement"), liaise (from "contact"), and look after children (sitter"). Indeed, when we use the verb back form (Did you know that "opt" was back-formed from "option"?), we are using a backformation.

g) Yule (2010) has stated that a process when a word is created by adding an affix in which the results meaning and/or category is different from its base word is called derivation. One of the kinds of word-development of slang language utilized in 1cak.com is inference or attachment, which is the way toward including a join. Normally, there are three types of affixes, namely; prefixes, suffixes, and infixes. From the data, there are 'wancaker', hater, 'hackersta', 'jokersta', and 'tentarasta' which are categorized in the suffix. The word 'wancaker' and hater originate from the first expressions of 'wancak' as the thing in grammatical feature and 'abhor' as the action word in the grammatical feature. These base words are then included with/ - r/postfix and the base words which are the thing (wancak) and action word (abhor) are changed into the importance of specialist or practitioner.

h) The acronym is a process whereby new words are formed from the initial letters or beginning segments of a set of words (Yule, 2010). Acronyms are shaped from the underlying sounds or letters of a few or the entirety of the words in an expression or title and afterward perusing them as a word. For example, ASAP (as soon as possible), YOLO (you only live once), and LOL (laugh out loud) show the acronym in 1cak.com. for example, the word GPL; is an acronym for Ga Pake Lama. OMG is an acronym for Oh My God. OL is an acronym for On-Line.

i) Multiple processes are forming some new words from old words through more than one wordformation process (Yule, 2010). For example, the word BBMan is an acronym that is derived from BlackBerry Messenger and then added a suffix /-an/at the end of that word. The word 'nge-date' (have a dating) is formed by the process of adding a prefix /nge-/ at the beginning of the word and combined by the process of borrowing from English (date).

Colloquial speech commonly uses to serve social purposes: to identify members of a group, to exchange the level of discourse in the direction of informality, to oppose established authority. Slang is a linguistics equivalent of fashion and serves the same purposes. According to Yachun and Yanhong (2013), there are three functions of slang, they are: a) Pursuit of self-identity, b) emotive feeling of the Slang Users, c) achieving politeness. In addition, according to Gerber (1968) that teens use slang words in sentences shorter, faster, and easier to say. Slang words also can express anger and accept unsettling experiences by translating the formal words into slang and getting a laugh (Guitar, 1963).

Language is an important thing in society. It is not only meant for communication and interaction but also for establishing and maintaining human relationships. Language is generally defined as a means of communication in social life. One of the characteristics of a language is social. All human being uses languages to interact with other people in society. Language is not only used as an instrument of communication but also as a means of individual society language is not instinctive. According to Wardhaugh (2006), language is an important means of communication that demonstrates human social behavior. It is a human personality, and that is the reason we use language to send and get messages about what our identity is, the place we are from, and whom we are related with. The relationship between language with adolescents is very close. Language in its development can be divided into several parts. One of them is University students' utterances or what is often known as colloquial speech.

SALTeL Vol.4, No. 1, 2021: 1- 10 
Slang, as characterized, is a lot of informal words or expressions in a language. Slang is generally perceived as the language of the youth. It seems like a part of youth culture and styles. People of the young generation use slang for multidimensional purposes. Sometimes slang is used as a secret code among the youth. At the point when they need their discourse ought not to be comprehended by the individuals of different ages. Once in a while slang is utilized to make fun and edification in the well-disposed conversation and tattle among the adolescent. The most important function of slang is the identity marker. It identifies the youth from the other generations.

Slang or Colloquial Speech many used by University Students'. University Students utter it when they talked with their friend. Colloquial speech that University students utter usually created by their creativity. University students' utterances have several special characteristics, namely brief and creative. The utterance was developed from small groups to spread and spread throughout the country.

\section{Method}

This research uses the descriptive qualitative method as an approach for exploring and understanding the meaning individuals or groups ascribe to a social or human problem. The process of research involves emerging questions and procedures, data typically collected in the participant's setting, data analysis inductively building from particulars to general themes, and the researchers making interpretations of meaning the data (Creswell, 2014).

In collecting data, the researcher has done interviews and records to take samples of the participant. The researcher applied a qualitative descriptive research method with the theory of types of colloquial speech according to Yule (2010) as a detailed explanation. The research subject was students majoring in the English department at the language and art faculty, State University of Medan. Participant observation and interviews were the technique in collecting data in the context of the situation in the class, in the library, in the cafeteria and surrounding the campus.

\section{Results and Discussion}

Colloquial is a language that has a unique style, colorful words, and characterized by various social groups. There is no specific time or period in using colloquial speech. Its usage just depends on how popular and new the word is. The newer words or terms that are used then it will be more popular and trends on social media hashtags. The colloquial speech shows the identity in social life and cohesiveness in a group or with a trend or fashion in society.

4.1 Table the Number of Colloquial Speech

\begin{tabular}{clcc}
\hline No. & \multicolumn{1}{c}{ COLLOQUIAL SPEECH } & Number & Percentage (\%) \\
\hline 1. & Coinage & 20 & 40 \\
2. & Borrowing & 6 & 12 \\
3. & Compounding & 1 & 2 \\
4. & Blending & 11 & 22 \\
5. & Clipping & 2 & 4 \\
6. & Backformation & 0 & 0 \\
7. & Derivation & 0 & 0 \\
8. & Acronyms & 8 & 16 \\
9. & Multiple Process & 2 & 4 \\
& & $\mathbf{5 0}$ & $\mathbf{1 0 0}$ \\
\hline
\end{tabular}

1. Coinage

a. Sultan

Maria : Banyak kali pesananmakanmu, Dit!

Dita : Oh, iya dong, anak sultan bebas mau pesan dan makan apa aja.

Maria : Iyalah yang kaya itu.

Maria and Dita go to the canteen for lunch. When sitting together and began ordering food, Maria saw the food that was ordered by Dita. There were so many orders she made that Maria questioned what Dita was doing by ordering so much food. But Dita doesn't care what Maria says, Dita just says it's free to buy whatever you want as long as you're a rich kid. There is no prohibition on how many orders she makes as long as she can pay.

Maria uses the word sultan, which means rich people. In KBBI, the word sultan is a term for the king or monarch. But now the word sultan is a term used to refer to rich people, 
lavish lifestyles, or even pretending to be rich. People who are considered 'sultans' are usually people who like to buy branded goods and to say they will buy an item at a high price is not difficult because they will buy the item casually without thinking before acting. In other words, 'sultan' is a group of people who casually spend a lot of money without any consideration of anything else in the future.

b. Galau

Tami : Kenapa itu wajah murung gitu?

Ayu : Galau dia tu, tugasnya enggak siap-siap, sementara waktu pengumpulannya sebentar lagi.

Tami : Kebiasaan pula, nunggu dekat harinya baru dikerjakan.

Tami, Amel, and Ayu sat in the class together. When Tami saw Amel, the expression that appeared by Amel was gloomy so Tami questioned the reason. Afterward, answered by Ayu who's right next to Amel. Ayu answered by describing Amel's feelings at that time, upset. Amel is Ayu and Tami's friend who always do the assignment when the gathering day is very close. However, work on the assignment that will be collected today is not as usual. Even though it is very close to the time of collection (deadline), Amel will still be able to finish and collect it but at this time is a concern for Amel because of her unfinished work.

According to the KBBI 'galau' has several meanings. In a noun, 'galau' means confused, chaotic. While as an adjective, 'galau' means sadness and anxiety. These adjectives that describe distorted thoughts are often used by students in their daily lives. In order words, the word 'galau' (confusion) has two meanings, the first is to describe a feeling that is confused or like being faced with two choices. The second meaning, confusion can be interpreted as an expression where the expectations do not match with the reality of the moment. The word confusion also develops meaning because it is often used in social media or conversations.

2. Borrowing

a. Absurd

Sinta : Ngapain disitu?

Rima : Lagi ngeliatin semut di pohon ini.

Sinta : Absurd lo.

A group of ants near Rima sat attracting Rima's attention. Sinta, who looks at Rima's activities is curious because she just stays silent, looks, and focuses on the thing and then asks Rima what she is doing. After getting an answer from Rima that she was staring at a group of ants walking in a tree, Sinta called Rima absurd because she thought that what Rima was doing was something strange and raised questions in her mind why doing such a thing.

The word Absurd is derived from English which means weird and unusual. The word absurd is often used by today's kids to describe the nature of someone and also the moment. An absurd trait is a sign of someone or something that looks impossible and tends to make no sense. while for the moment field, absurd means an event or condition which is seen is very unlikely to happen or even makes no sense if the thought of.

b. Afwan

Andi : Citra, minumnya tumpah di atas meja ini

Citra : Mana? Afwanya (sambil tersenyum menampakkan giginya)

Andi : Iya, dibersihin dulu baru dimaafin.

Citra and Andi are sitting at the canteen enjoying hours of rest while drinking and eating the food that was ordered. Moreover, Andi accidentally spilled the drinks on the table so that the table and items soaked on it. Feeling guilty, Andi said 'afwan' while giving a smile that expressed regret to Citra for apologizing for what he had done. Citra that was not too concerned about the incident only asked Andi to wipe the water on the table as accountability and apologize for the act that he did not intentionally do.

The word 'afwan' is taken from Arabic which means sorry. According to Yule, the words is borrowed from other countries' languages are part of borrowing colloquial speech. This word is often used by today's child that refers to a group of friends or Moslem. Although 'afwan' means sorry, people nowadays say the word for excuse whether just to pass or excuse that related to other things. 'Afwan' can also mean you're welcome, no problem, or 
my pleasure. It means after someone thanks and the doer of kindness can only give/do that much.

3. Compounding

a. Trollface

Jimin : Joon, fotoyuk (mengarahkan kamera ke wajah mereka berdua)

Joon : (bergaya di depan kamera)

Jimin : (mengambil 1 foto) lagi...lagi...lagi... kali ini troll-face ya

Joon : (bergantigaya)

Jimin : (mengambil 1 foto lagi) oke... coba kita lihat.

Jimin invited Joon who was reading a book to take a picture. Joon agreed and both of them pose in front of the camera. Jimin took one photo of them then told Joon to do it again. This time Jimin told Joon to change his style to a troll-face pose. Afterward, make their faces look weird and ugly in front of the camera. Jimin took one more photo. They look at the photos taken by Jimin and laugh together because they see their own strange and ugly faces.

The term troll-face or ugly face is a combination of troll and face. Trollface is the word from the IT world (internet slang words) which is a sketch of a face with a very wide smile and very distinctive. The more precisely is a depiction of expressions that comes in various forms, such as sun, cabinets, which are essentially bad luck. A troll face is a facial expression that expresses sarcasm or a veiled form to mock someone after saying or doing something very stupid and ignorant to make people emotional, particularly angry. Trollface is one of the most used memes. The inventor of this meme is Whynne from DeviantART.

4. Blending

a. 'Baper'

Daniel : Eh. Gendut, pinjam buku dong.

Jimin : Kalau mau pinjam yang baguslah ngomongnya, gak usah main fisik segala.

Daniel : Santai laaa... Gitu aja baper. Aku kan cuma becanda.

Daniel intends to borrow Jimin's book. He asked Jimin but he called Jimin fat because Jimin a little bit look fat, moreover they were friends so Daniel felt it is not a big deal calling Jimin like that. Jimin did not accept the way daniel called him. Look at the condition, daniel is someone who needs helping hands and he has to ask Jimin for help. Comparing with the situation, Daniel should have used polite words. Daniel called Jiminbaper because he thought Jimin was too emotional in responding to his jokes.

The first syllable of the word 'bawa' (carry) combined with the first syllable of the word 'perasaan' (feeling/emotional) will produce the word 'baper' (take everything in a serious way/bring the feeling). The word 'baper' is a slang term that is created by millennials and was popular in 2014 until now. As a matter of fact, the term 'baper' became the most searched word on Google in 2015. 'Baper' itself is often used to describe situations or events that make you feel carried away. Oftentimes, the word 'baper' is associated with romantic things, for instance when someone you like is chatting you with or 'baper' when you see someone you like turns out to like someone else.

b. Caper

Jimin : Biar saya aja yang bawa bukunya ke kantor, sir. (dari kejauhan memandangi jimin)

Daehwi : Liat tuh si Jimin mulai capernya dia. Biar dapat nilai A dari Sir Syamsul itu.

Jenni : Dia mah memang suka caper orangnya.

Jimin offers a helping hand to help his lecturers to bring his books to the office. Daehwi and Jeni who saw the actions of Jimin considered him as a caper because they felt Jimin was not sincere in helping the lecturer, he just wanted to get attention, be considered as a good student, and get good grades from the lecturer.

'Caper' is a combination of the words 'cari' (looking for/search) and 'perhatian' (attention). The combination of two or more words to produce a new single term is categorized into blending in colloquial speech. The word 'Caper' means Looking for Attention. The goal of Millennials and Gen Zs to use this cool term today is to signify someone who likes to be the foremost anywhere and anytime. Moreover, the trend of the caper is used as a caption in social media such as IG FB of young people nowadays.

\section{Clipping}


a. Gan

Daniel has a lot of assignments that he has to collect to the class monitor this morning. Before going to the campus, he prepared everything including the assignment. Daniel has arrived at the university and looking for a place to print out the assignment directly. Daniel asked the price to bind the paper. He called the person, gan because the person was the owner of the stationery shop and was a man.

Daniel : Berapa harga jilid makalahnya, gan?

Pemilik : Lima ribu aja.

Daniel : Ini, gan. Makasihya...

Daniel asked the price to bind the paper. He called the person, bro because the person was the owner of the stationery shop and was a man. The word 'gan' / 'agan' comes from the habits of the Jakarta teenagers who greet their friends with 'gan' / 'agan' terms. If examined properly, the word gan / agan comes from the word 'JURAGAN'. In other words, the word gan is representative of the entire word by the first syllables from 'juragan' (the skipper). 'JURAGAN' itself has a positive meaning or meaning, this gan / agan greeting is having a

6. Acronyms good purpose, which is to respect and appreciate the person being addressed.

a. $\mathrm{MBB}$

Lisa : Dimana, Jen? Aku udah di kampus ini. (beberapa menit kemudian)

Jenni $\quad$ :MBB ya. Aku di jalan dekat kampus sekarang, udah dekat ini.

Lisa: Oke.

Lisa asks Jeni's location through an application for exchanging messages because they have agreed (have an appointment) to meet on campus but Lisa hasn't seen Jeni's at the campus. Jeni replies to Lisa's message with a long duration of time when Lisa sends a message because she's on her way. She replies with the MBB to apologize for taking a long time to reply to Lisa's message because she was on her way and told Lisa that she was already close to campus so that Lisa knew that she was keeping their promise to meet on campus. After Lisa knows where Jeni is she felt calmer.

MBB is an acronym for Maaf Baru Balas (sorry for being late in replay). MBB was entered into the slang language that called a variety of non-standard Indonesian language that is commonly used by young people in everyday relationships or daily life. MBB consists of three characters and only has one meaning. The acronym is taken from the first letter of $\mathrm{M}$ from Maaf (sorry), the first B is taken from the word Baru (new or just), and the second B is taken from the word Balas (Reply). The word MBB is used when someone being late in reply to a message from someone else.

b. JJS

Jeka invites Jimin to go to campus. Jimin wondered why Jeka was taking him to the university in the afternoon when they haven't a class. Jimin asked the purpose of Jeka's invitation just to take a walk in the afternoon around their campus area because there will be many people running at that time. Jeka just thought it would be fun.

Jeka : Rose, ke kampus yok

Rose : Ngapain sore-sore gini ke kampus?

Jeka : JJS sekali-kali di kampus, kan jam segini banyak orang lari sore.

The current development affected the language used in adolescents today. In other words, language usage improved time by time. One of the results of language development is an abbreviation in everyday life. The abbreviation is something that must be known among teenagers. In Yule (2010) the abbreviation in the language is called acronyms which is a type of colloquial speech. for instance of the acronyms is JJS. The word JJS is an acronym for a walk in the afternoon. The acronyms are a combination of the initial consonants of the three syllables, Jalan (walks), Jalan (walks), and Sore (afternoons).

7. Multiple Process

a. Unfaedah

AL : Ohh iya, aku lupa. Laptopku gak bisa sambung ke proyektor

Gigi : Yaaaa, jadi gimana? Unfaedah kali kau bawa laptop mu itu. Gak bisa dipakai.

AL : Yauda, pinjam sama yang lain aja yaaa.

Gigi and $\mathrm{Al}$ groups got their turn to present in front of the class today. They agreed to use

SALTeL Vol.4, No. 1, 2021: 1-10 
Al's laptop during the presentation. $\mathrm{Al}$ agreed about the thing, but he forgot that his laptop could not be connected to the projector without additional cable. Al just remembered when they started preparing equipment for presentations. Gigi who just found out about this said 'unfaedah' to brought the laptop because the laptop could not be used for presentations. Realizing this, Al finally decided to borrow another friend's laptop.

The word 'unfaedah' is the opposite of the word or negative word of 'faedah' ie, useless or unprofitable. 'Un' is one of the prefixes in English which means 'not'. The addition of 'un-' itself is an addition given to make the meaning negative in English. Furthermore, the prefix 'un' is used to give opposite and negative meanings to adjectives, adverbs, and nouns.

b. Ber-flower

Siti : Kenapa ya mahasiswa di kelas kita ini gak bisa tertib kalau lagi di dalam kelas, selalu berisik

Budi : Maklum aja, namanya juga mahasiswa Negara Ber-flower.

Siti: Iya pula yaa

Siti complained about his friends who could never be orderly while in class. The students are always making a fuss and riots. Budi who heard Siti's complaints told him to understand the place (country) where they lived and growth as the reason. 'Negara berflower' or developing country that was identical to disorganized, lazy, and crowded people. The word 'ber-flower' is a combination of the Indonesian prefix 'ber' with the word 'flower'. 'Flower' is English for 'kembang' (Javanese). This term is often used to refer to Indonesia itself. The word 'ber-flower' is usually used together with the word 'negara' (country) to produce the word of 'negara ber-flower' (developing country). 'Negara ber-flower' (the flowering nation) itself is a netizen nickname for Indonesia. The reason is that Indonesia is indeed a developing country. The word is usually used to show the unique behavior of Indonesian people. Moreover, the word 'ber-flower' never stands alone and is always pair with the word Negara (country).

\section{Conclusion}

The changing of time will affect changes in the language used. The language change meant is the informal language used in daily life by teenagers (today's kid) or better known as colloquial speech. The use of this language is often heard everywhere, particularly when hanging out or gathering together with friends. Every word included in the colloquial speech is a general word that every society knows.

Yule (2010) divides types of colloquial speech into nine parts, coinage, borrowing, compounding, blending, clipping, backformation, derivation, acronyms, and multiple processes. Coinage, blending, and acronyms are types of colloquial speech that tend to be used by today's kids.

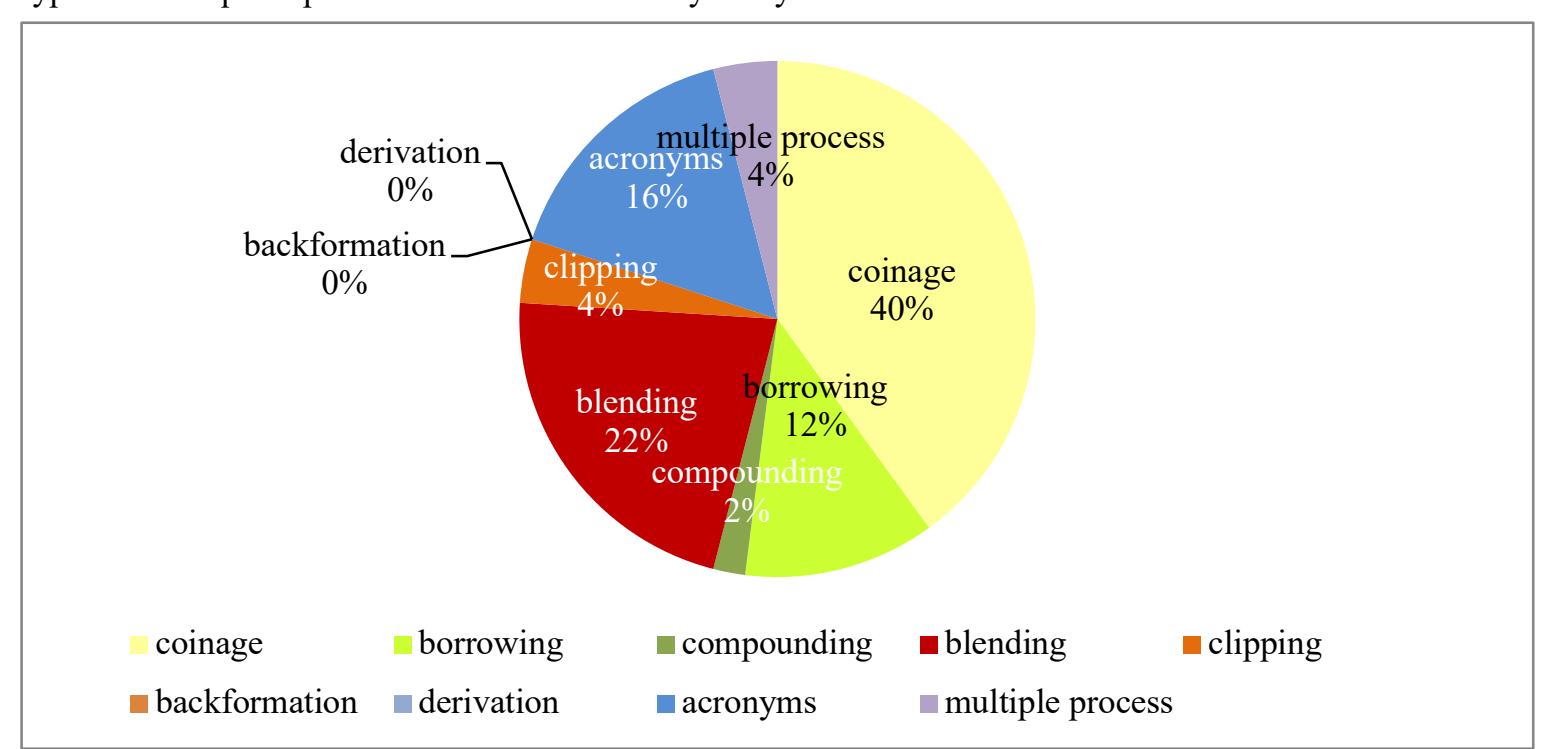

Coinage has become a trend in its use because of reasons to make someone who utters look cooler. The terms that emerge cannot be understood just by hearing the word, but also must have relationships and friendship with groups of hits people. Whereas blending and acronyms often arise because of shorter usage, whether abbreviated words by combining two or more syllables or abbreviated words using only the initials letters. Moreover, colloquial speech is more spoken instead of written text. 


\section{References}

Chaer, A. (2003). Linguitik Umum. Jakarta: PT. Rineka Cipta.

Epoge, N. K. (2012). Slang and Colloquialism in Cameroon English Verbal Discourse. International Journal of Linguistics, 130-145.

Fernandez, A., Matamala, A., \& Vilaro, A. (2014). The Reception of Subtitled Colloquial Language in Catalan: An Eye-Tracking Exploratory Study. Vigo International Journal of Applied Linguistics, 6380.

Gerber, P., \& Rosenblum, E. N. (n.d.). Proc. Soc. Exp. Biol. Med. 541-546.

Holmes, J. (2001). An Introduction to Sociolinguistics (2nd). London: Longman.

Izmaylova, G. A., Zamaletdinova, G. R., \& Zholshayeva, M. S. (2017). Linguistic and Social Features of Slang. International Journal of Scientific Study, 75-78.

Jalalpour, E., \& Tabrizi, H. H. (2017). A Study of English Translation of Colloquial Expressions in Two Translations of Jamalzadeh: Once Upon a Time and Isfahan Is Half the World. Journal of Language Teaching and Research, 1012-1021.

Lantto, H. (2012). Code-switching, swearing, and slang: The Colloquial Register of Basque in Greater Bilbao. International Journal of Bilingualism, 634-648.

Nababan. (1993). Sosiolinguistik Suatu Pengantar. Jakarta: Gramedia Pustaka Utama.

Rahardi, K. (2001). Sosiolinguistik Kode dan Alih Kode. Yogyakarta: Pustaka Pelajar.

Yule, G. (2010). The Study of Language. America: Cambridge University Press.

Zamaletdinova, G. R., \& Izmaylove, G. A. (2016). Features of Youth Slang Functioning. International Journal of Humanities and Cultural Studies, 563-572. 